\title{
Sea blue histiocytosis in a patient with chronic non-neuropathic Niemann-Pick disease
}

\author{
N. DEWhuRSt, G. T. N. Besley, N. D. C. Finlayson, AND A. C. PARKER \\ From the Department of Medicine, University of Edinburgh, the Department of Pathology (Royal Hospital \\ for Sick Children), University of Edinburgh, the Gastrointestinal/Liver Service, and the Department of \\ Haematology, Royal Infirmary, Edinburgh, UK
}

SUMMARY A patient with Niemann-Pick disease is reported together with family studies. Her liver and bone marrow were shown to be infiltrated with sea blue histiocytes. Other organs, spleen and lung, were presumably also involved but histological proof was not obtained. Enzyme assay of leucocytes, lymphocytes, and cultured skin fibroblasts showed the patient to be deficient in sphingomyelinase activity. In fibroblasts, activity was $5 \%$ of normal while for the parents activity was about $50 \%$ of normal. The expected partial deficiency was not found using leucocytes or lymphocytes from the parents. Heat stability studies on fresh fibroblast extracts from the propositus indicated that residual sphingomyelinase activity was slightly more labile than that of the controls. It seems clear that chronic Niemann-Pick disease without neurological involvement is associated with sea blue histiocytosis.

In 1947, the term 'blue histiocyte' was used by Moeschlin (1947) to describe macrophages found in the spleen of an adult with unexplained splenomegaly. The cytoplasm of these cells was packed with numerous granules of varying sizes which stained blue with Romanowsky dyes. Silverstein et al. (1970) coined the term 'syndrome of the sea blue histiocyte' to describe a relatively benign condition characterised by hepatosplenomegaly and mild thrombocytopenia. This syndrome has been extensively reviewed by Sawitsky et al. (1972) and Silverstein and Ellefson (1972).

Sea blue histiocytes have also been recorded in a wide variety of other conditions, including such diseases as chronic myeloid leukaemia (Steinberg and Dreiling, 1973) and abnormalities of lipid metabolism such as lecithin-cholesterol acyl transferase deficiency (Hovig and Gjone, 1973). In 1964, Lynn and Terry described a patient with adult Niemann-Pick disease and found foamy cells in the marrow which resembled sea blue histiocytes. Golde et al. (1975) reported partial deficiency of sphingomyelinase in the fibroblasts of three siblings with sea blue histiocytosis. Further cases of this association have been described (Long et al., 1977; Wenger et al., 1977; Fried et al., 1978). In this report we describe a

Received for publication 23 April 1979 further patient suffering from non-neuropathic Niemann-Pick disease. Full clinical, biochemical, and ultrastructural details are described. The family differs in certain significant respects from previously published cases.

\section{Case report}

The patient, the youngest of four children, was born to Scottish parents who were not related, and there was no significant family medical history. She was delivered at term and examination at birth was normal. No perinatal complications were recorded, and she achieved her motor milestones at the appropriate age.

She presented to hospital aged 7 years with listlessness, abdominal pain, and distension. Examination revealed a thin girl below the third percentile for both weight and height. Other significant clinical findings were enlargement of the liver to $12 \mathrm{~cm}$ and the spleen to $8 \mathrm{~cm}$ below the costal margin, palmar erythema, and spider naevi. Neurological examination was normal and there was no evidence of intellectual impairment. Haemoglobin, white blood count, platelets, and liver function tests were also normal. A chest $x$-ray showed a reticulostriate pattern suggestive of a diffuse infiltration. Liver biopsy was performed at laparotomy and 
Table 1

\begin{tabular}{|c|c|c|c|c|c|c|c|c|c|c|}
\hline \multirow{2}{*}{$\begin{array}{l}\text { Prothrombin } \\
\text { ratio }\end{array}$} & \multirow{2}{*}{$\begin{array}{l}\text { Partial thromboplastin } \\
\text { time/kaolin }\end{array}$} & \multirow{2}{*}{$\begin{array}{l}\text { Fibrinogen } \\
(g / l)\end{array}$} & \multirow{2}{*}{$\begin{array}{l}\text { Platelets } \\
\left(\times 10^{\circ} / l\right)\end{array}$} & \multirow{2}{*}{$\begin{array}{l}\text { Bleeding time } \\
\text { (min.) }\end{array}$} & \multicolumn{6}{|c|}{ Factor $\%$ of normal } \\
\hline & & & & & $I I$ & $\boldsymbol{V}$ & $V I I$ & $V I I I$ & $I X$ & $X$ \\
\hline
\end{tabular}

microscopic examination revealed numerous foamy histiocytes. No specific diagnosis was made. She received no treatment and was seen regularly until she was 15 years old. She remained well, clinically unchanged, but subsequently was lost to follow-up.

She was readmitted to hospital aged 25 years complaining of progressive abdominal distension, ankle swelling, and general malaise. Examination confirmed the signs noted previously, and, in addition, she was sexually immature with small breasts and almost no pubic or axillary hair. She was very pale and had ascites and considerable peripheral oedema. Examination of the nervous system was again normal.

The haemoglobin was $4.4 \mathrm{~g} / \mathrm{dl}$ with hypochromic microcytic red blood cells, shown subsequently to be due to iron deficiency. Red blood cell survival measured with chromium-51 (Dacie and Lewis, 1975) showed a shortened half-life of 17 days and a splenic red cell pool of 0.1451 (upper limit of normal 0.036).
In addition, the plasma volume was expanded at $0.591 / \mathrm{kg}(0.04-0.05)$. The white cell count was $1.5 \times 10^{9} / 1$ (neutrophils $0.8 \times 10^{9} / 1$ ) and the platelet count $95 \times 10^{9} / 1$. The concentration of clotting factors in the blood was also abnormal; factors II, V, VII, IX, and X (Dacie and Lewis, 1975) were reduced (Table 1) and the prothrombin ratio, $1 \cdot 6$, failed to correct after an adequate dosage of vitamin $K$. Chromosomal studies revealed a normal female karyotype. Bone marrow aspiration yielded hypercellular normoblastic marrow. This was infiltrated with abnormal cells, some of which closely resembled sea blue histiocytes in both colour and size (Fig. 1); others had foamy cytoplasm (Fig. 2). The inclusions were only weakly PAS positive. Electron microscopy was also performed (Fig. 3). The cells were large and contained numerous vacuoles lined with single membranes which contained loosely packed lamellar structures.

Liver function tests were abnormal (bilirubin 29

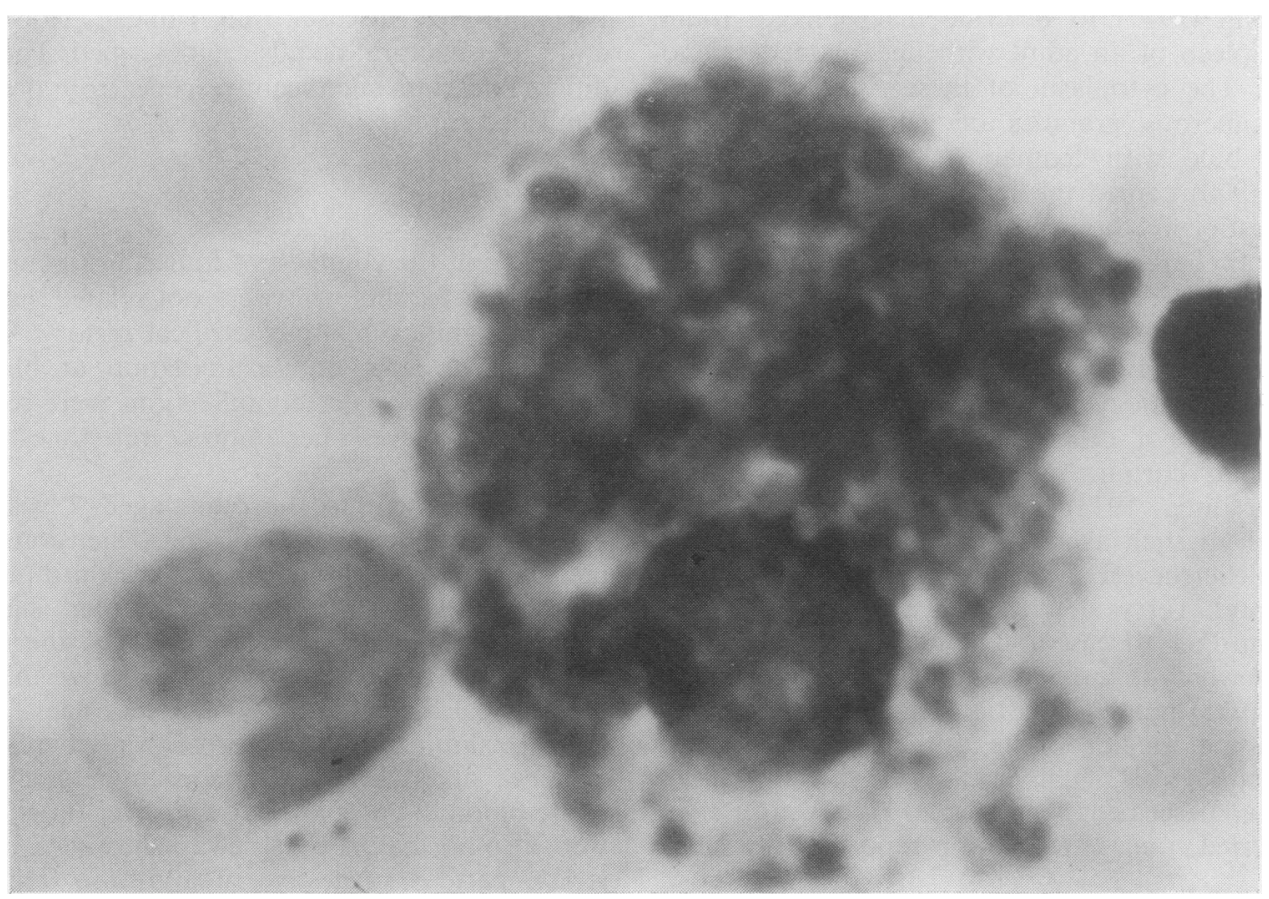

Fig. 1 A 'typical' sea blue histiocyte encountered in the patient's bone marrow. $(\times 2300)$ 


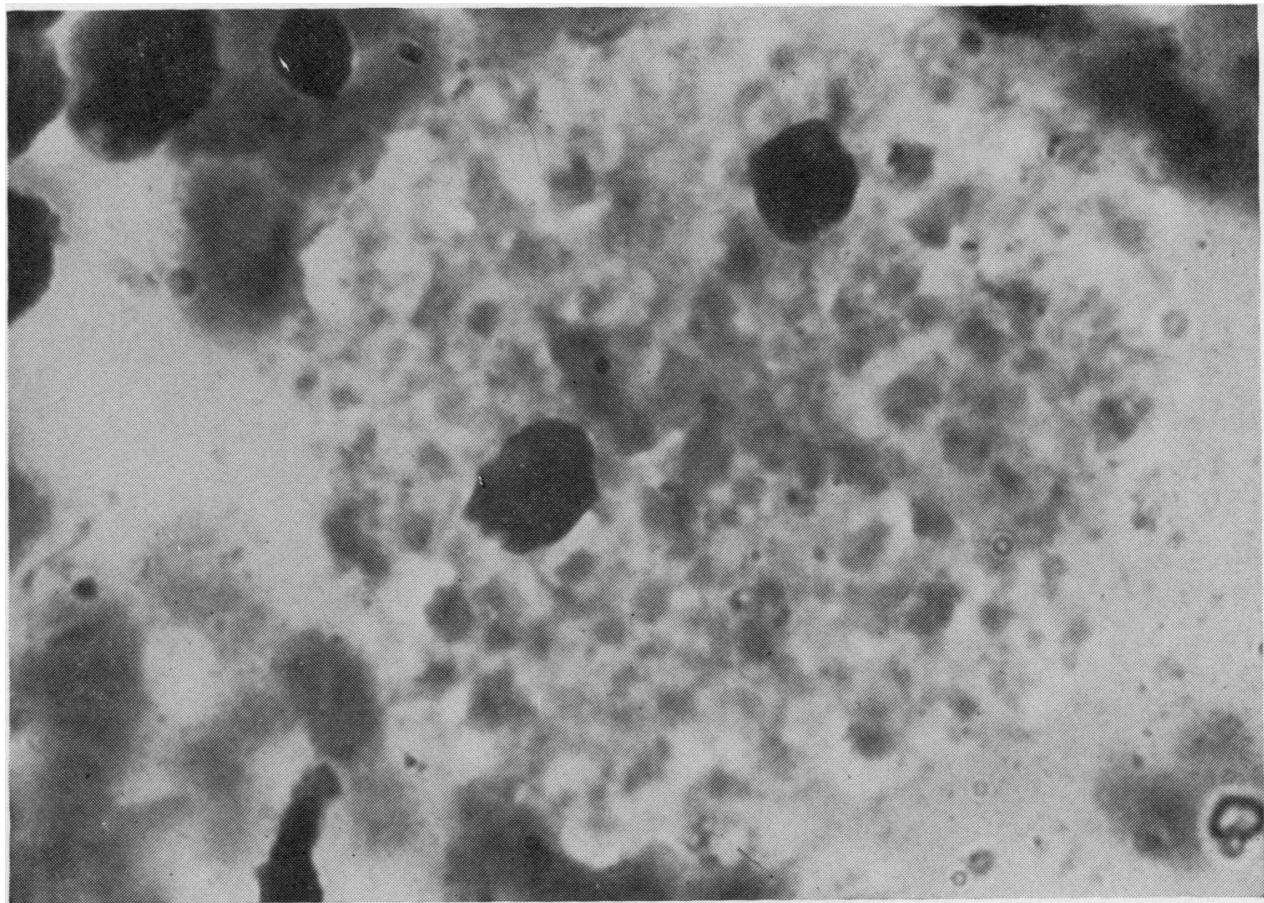

Fig. 2 A degranulated giant cell in the patient's bone marrow. $(\times 2300)$

$\mu \mathrm{mol} / 1(2-17 \mu \mathrm{mol} / \mathrm{l}) ;$ alanine aminotransferase 19 units/1 (10-40 units/1); alkaline phosphatase 343 units/1/liver origin (40-100 units/1); total protein $64 \mathrm{~g} / 1(60-80 \mathrm{~g} / \mathrm{l})$; albumin $31 \mathrm{~g} / 1(36-47 \mathrm{~g} / \mathrm{l})$. A liver biopsy was not performed, and a barium meal did not reveal oesophageal varices.

A chest $x$-ray showed generalised infiltration as before, and pulmonary function tests showed a mild restrictive defect $\left(\mathrm{FEV}_{1} 1.95 \mathrm{l}\right.$, FVC 2.21 ; predicted $2 \cdot 5,2 \cdot 8)$ with a diminished transfer factor for carbon monoxide $4.34 \mathrm{mmol} \mathrm{ml}^{-1} \mathrm{kPa}^{-1}$ (predicted 8.53).

\section{BIOCHEMICAL STUDIES}

Leucocytes were separated from fresh heparinised blood after dextran sedimentation (Snyder and Brady, 1969) and lymphocytes were isolated by Ficoll-Hypaque sedimentation (Boyum, 1968). The cells were washed in isotonic sodium chloride and stored for up to two months as pellets at $-70^{\circ} \mathrm{C}$. Fibroblasts were grown from forearm skin biopsies. The cells were cultured in Ham's F10 medium containing $15 \%$ fetal calf serum and antibiotics; when confluent, they were removed by trypsin digestion $(0.25 \%(\mathrm{w} / \mathrm{v})$ trypsin and $0.04 \%(\mathrm{w} / \mathrm{v})$ EDTA in phosphate buffered saline). The cells were washed and stored as for leucocytes.

For thermal stability studies fibroblast extracts were treated as described (Schneider et al., 1978).
Fresh extracts were preincubated at $50^{\circ} \mathrm{C}$ in the presence of $25 \mathrm{~mm}$-citrate-phosphate buffer, $\mathrm{pH} 6.0$, containing $10 \mathrm{mg} / \mathrm{ml}$ sodium taurocholate (crude extract, Sigma Chemical Co Ltd) and $2 \mathrm{mg} / \mathrm{ml}$ Cutscum (kindly donated by $\mathrm{Dr}$ A. D. Patrick, London).

For enzyme assay, pellets were extracted with sodium cholate (Besley, 1977), and sphingomyelinase activity was determined using both the natural substrate $(N$-methyl-14 $\mathrm{C})$-sphingomyelin (Radiochemical Centre, Amersham, Bucks) and its chromogenic analogue, 2-hexadecanoylamino 4-nitrophenylphosphorylcholine (HNP, Koch-Light Labs Ltd). Assay with the natural substrate was as described previously (Besley, 1977). The incubation mixture $(0.2 \mathrm{ml})$ contained cell extract $(50-200 \mu \mathrm{g}$ protein), $250 \mu \mathrm{g}$ sodium cholate, $68 \mathrm{nmoles}\left({ }^{14} \mathrm{C}\right)$ sphingomyelin $(40000 \mathrm{cpm}), 20 \mu$ moles sodium acetate buffer, pH 5.0, and $0.025 \%(\mathrm{v} / \mathrm{v})$ Triton $\mathrm{X}-100$. Incubation was for 2 hours (fibroblast extracts) or 3 hours (white cell extracts). Assay of sphingomyelinase activity with HNP was as described by Gal et al. (1975), but, in the presence of $0.05 \%$ (v/v) Triton X-100 and $\beta$-hexosaminidase activity, was determined (Besley, 1977) using 4methylumbelliferyl-2-acetamido-2-deoxy- $\beta$-D-glucopyranoside (Koch-Light Labs Ltd) as substrate. Protein was measured (Lowry et al., 1951) using 


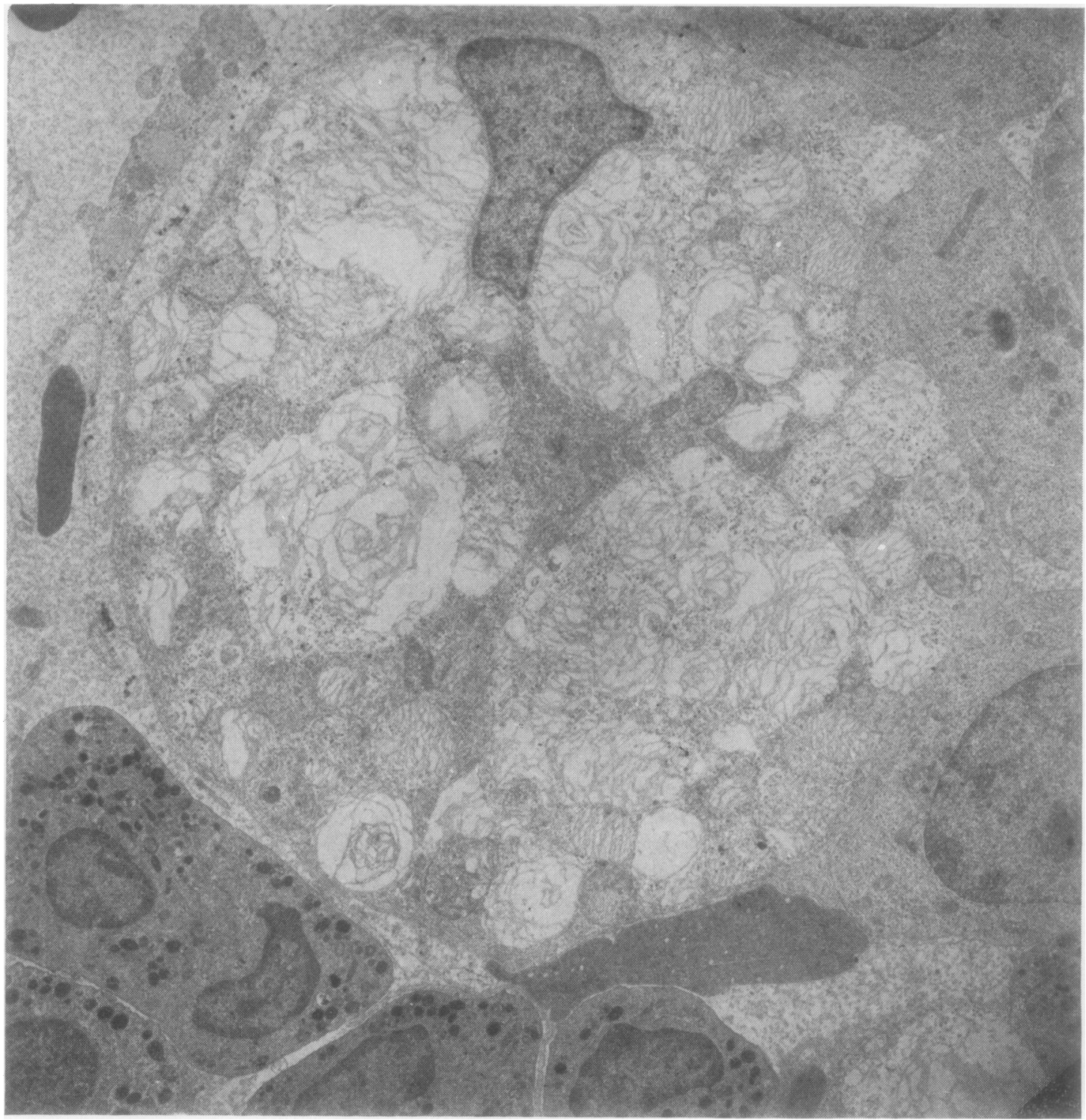

Fig. 3 Electron microscopic appearance of the 'sea blue histiocyte' in the patient's marrow. $(\times 6000)$

bovine serum albumin as standard.

Tables 2 and 3 summarise sphingomyelinase activities of white blood cells. In lymphocytes, activities were two to three times higher than those of dextran-separated leucocytes, the preparation generally used for the investigation of lysosomal storage disorders. For each cell preparation, sphingomyelinase activity was markedly deficient in cells from the affected case, but in lymphocytes the deficiency $(6 \%$ of controls) was more pronounced. Neither cell preparation exhibited the partial enzyme deficiency expected for both parents (obligate heterozygotes). Although erythrocyte contamination was evident in the maternal lymphocyte preparation, the activity of a reference enzyme, $\beta$-hexosaminidase, indicated that neither contamination nor incomplete enzyme extraction was responsible for the low sphingomyelinase activity in these heterozygous lymphocytes.

Sphingomyelinase activity in cultured fibroblasts was considerably higher (Table 4) than in white blood cells, and consequently activity could also be 
Table 2 Sphingomyelinase activities of dextransedimented leucocytes

\begin{tabular}{lll}
\hline Subject & $\begin{array}{l}\text { Sphingomyelinase activity } \\
\text { (nmoles/h per mg protein) }\end{array}$ & $\begin{array}{c}\% \text { Mean } \\
\text { control value }\end{array}$ \\
\hline Proband & 0.34 & 13 \\
Father & 2.39 & 91 \\
Mother & 1.15 & 44 \\
Controls (n = 12) & & \\
Mean \pm SD & $2.64 \pm 0.97$ & \\
Range & $1.57-5.26$ & \\
\hline
\end{tabular}

Table 3 Enzyme activities of separated lymphocytes

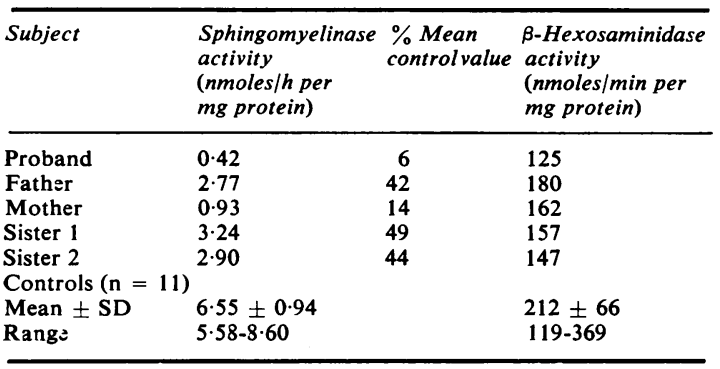

determined with the artificial substrate, HNP. Using this analogue, activities were about twice those measured with the natural substrate, and the values obtained with each substrate correlated well with each other. Sphingomyelinase activity of fibroblasts from the affected case was about $5 \%$ of control values, and mixing experiments carried out on these extracts and controls established that this reduction did not result from the presence of an enzyme inhibitor. Fibroblasts derived from the parents had about $50 \%$ of control values, which is consistent with the disorder being inherited in an autosomal recessive manner. Activities of fibroblasts from the sibs segregated well into normal unaffected homozygous (brother and sister 2) and heterozygous (sister 1) values.

Heat stability studies indicated that sphingomyelinase activity in the patient's fibroblasts was somewhat more labile than that of the controls. At $50^{\circ} \mathrm{C}$ the half-life was 18 minutes as compared with 28 and 46 minutes for two controls and 43 minutes for a case of Niemann-Pick disease (GM-645, Human Genetic Mutant Cell Repository, New Jersey) whose residual activity was similar to that in the present case. Generally, fibroblast sphingomyelinase activities were determined on cell pellets that had been stored at $-70^{\circ} \mathrm{C}$. These activities were similar to those measured on fresh extracts, and there was no evidence that the residual activity of fibroblasts from the propositus decreased during storage.

\section{Discussion}

It is usual at present to classify Niemann-Pick disease into an infantile, well-defined clinical entity which is characterised by progressive mental and motor deterioration with hepatosplenomegaly (type A), and cases with organ infiltration but no neurological involvement (type B; Crocker, 1961). Recognition of the abnormality in these latter patients is frequently at a later age than in type A. The case we have described probably falls into the type B category, the patient having visceral infiltration and no neurological dysfunction. That she has Niemann-Pick disease is confirmed by the low sphingomyelinase levels (5\% of normal) in cultured fibroblasts. Of further interest in this patient was the finding in the marrow of cells morphologically identical with the sea blue histiocyte. At an early age her liver was infiltrated with large vacuolated cells but this was not investigated when she was seen on this occasion.

Two groups of disorders involving the sea blue histiocyte have been reported. The first is characterised by abundant sea blue histiocytosis in the spleen, liver, and bone marrow. In the second group, histiocytes are confined to the spleen and bone marrow, and other diseases frequently co-exist

Table 4 Enzyme activities of cultured skin fibroblasts

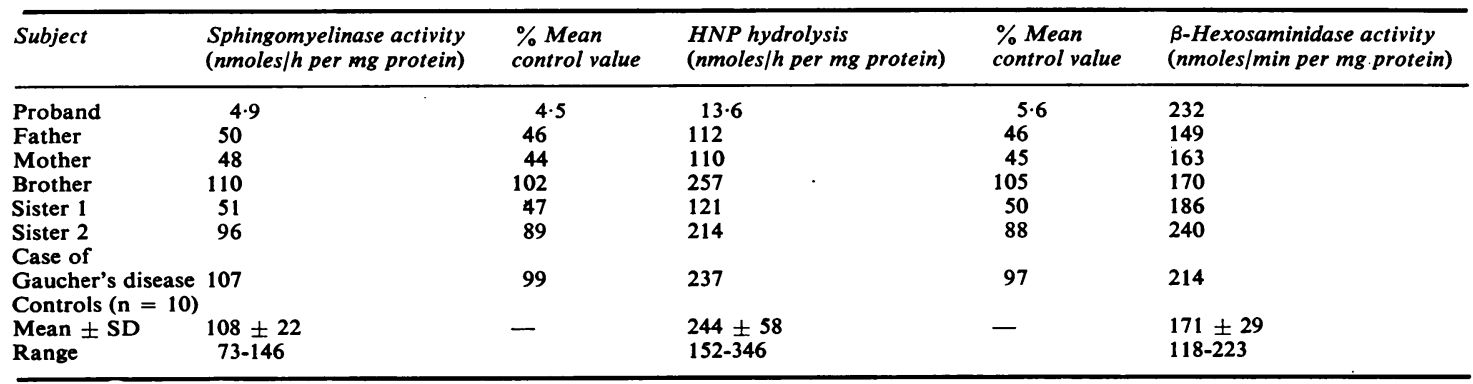


(Silverstein and Ellefson, 1972). It is likely that in some cases the sea blue histiocyte is a macrophage which has ingested large amounts of particulate lipid in the process of clearing such particles from the blood and tissues and cannot digest them (Parker et al., 1976). Though the precise biochemical defect cannot always be identified it seems reasonable to suggest that in most instances a structurally defective or partially or completely absent enzyme leads to an accumulation of its natural substrate within the cell, producing a cell morphologically similar to the sea blue histiocyte. We agree with Long et al. (1977) that the term 'syndrome of the sea blue histiocyte' should be discarded as it leads to confusion, and in any case such cells in different cases are probably p -oduced by dissimilar basic underlying defects. The presence of such cells in abundance, however, should initiate a search for an underlying cause. In adults and children, it is becoming clear that Niemann-Pick disease is a common cause of this uncommon clinical picture, and sphingomyelinase assay should be carried out in all cases.

Though there are recent reports similar to ours in the literature, most studies are incomplete. In many cases, in addition, the clinical and experimental features do not correspond to those of our own case. Until 1968 only three cases had been described. Lynn and Terry (1964) described a 19-year-old patient with foamy cell infiltration of bone marrow and lymph nodes. Sphingomyelinase was not measured nor was it measured in the three cases of Long et al. (1977), who resembled our patient clinically.

Of nine cases reported by Wenger et al. (1977), all had neurological involvement and thus are different from our family. In addition, the levels of sphingomyelinase reported did not approach the low level $(5 \%)$ seen in our patient, the lowest level in their patient being $12 \%$. In the case of Golde et al. (1975), in which sea blue histiocytes were well described, sphingomyelinase activity averaged $18 \%$ of control levels, but more recent evidence (Schneider et al., 1978) has shown that this residual sphingomyelinase activity is thermolabile. This new form of Niemann-Pick disease was designated type F. Two affected families were described in which the clinical expression of the disease closely resembled that of our patient. There was a considerable difference in terms of the amount of residual activity and the degree of thermal stability of sphingomyelinase in the two families described with Niemann-Pick disease type F (Schneider et al., 1978). Because of these differences it is not possible definitely to categorise our patient within this new group. Under the same assay conditions, sphingomyelinase activity in fibroblasts from our patient was similar to that (about $3 \%$ of controls) measured in two patients with Niemann-Pick disease type B but somewhat higher than that (less than $1 \%$ of controls) in four cases of Niemann-Pick disease type A.

Our results, in addition, show that the assay of sphingomyelinase activity in white blood cells may be of limited value in the recognition of heterozygotes, and consequently the state of the two sisters studied here could not be determined. The unreliability of such assay extends to lymphocyte preparations as well as to dextran-separated leucocytes in terms of heterozygote detection. Finally, the findings with regard to sphingomyelinase are consistent with an autosomal recessive inheritance of Niemann-Pick disease.

The coagulation abnormalities reported are similar to those found in the case of Long et al., though in our patient the bleeding time was normal despite the low platelet count. All the factors produced by the liver (II, V, VII, IX, X), apart from fibrinogen, were reduced; factor VIII was increased. This pattern is consistent with liver disease but it is not inconceivable that hypersplenism with resultant expansion in plasma volume (diluting the clotting factors) and increased intrasplenic utilisation of factors may contribute to such a picture. Certainly we have seen similar abnormal values in a young patient with massive splenomegaly, due to an unknown underlying cause, revert to normal after splenectomy (personal observations).

We have not performed splenectomy. In only one patient, closely resembling ours clinically, was splenectomy undertaken (Long et al., 1977). The result appeared satisfactory but the follow-up period was not specified. We are concerned that removal of the spleen in our patient might lead to more marked infiltration of vital organs, for example the lung and liver.

Our thanks are due to Dr A. E. Dewar, Department of Pathology, University of Edinburgh, for separating the leucocytes, and to Dr S. Hartley, Medical Research Council, for performing the cytogenetic analyses.

\section{References}

Besley, G. T. N. (1977). Sphingomyelinase defect in Niemann-Pick disease, type $\mathrm{C}$, fibroblasts. FEBS Letters, 80, 71-74.

Boyum, A. (1968). Isolation of mononuclear cells and granulocytes from human blood. Scandinavian Journal of Clinical and Laboratory Investigations, 21, Supplement, 97, 77-89.

Crocker, A. C. (1961). The cerebral defect in Tay-Sachs disease and Niemann-Pick disease. Journal of Neurochemistry, 1, 69-80.

Dacie, T. V.. and Lewis, S. M. (1975). Practical Haema- 
tology, 5th edition. Churchill Livingstone, Edinburgh and London.

Fried, K., Beer, S., Krespin, H. I., Leiba, H., Djaldetti, M., Zitman, D., and Klibansky, C. (1978). Biochemical, genetic and ultrastructural study of a family with the sea-blue histiocyte syndrome/chronic non-neuropathic Niemann-Pick disease. European Journal of Clinical Investigation, 8, 249-253.

Gal, A. E., Brady, R. O., Hibbert, S. R., and Pentchev, P. G. (1975). A practical chromogenic procedure for the detection of homozygotes and heterozygous carriers of Niemann-Pick disease. New England Journal of Medicine, 293, 632-636.

Golde, D. W., Schneider, E. L., Bainton, D. F., Pentchev, P. G., Brady, R. O., Epstein, C. J., and Cline, M. J. (1975). Pathogenesis of one variant of sea-blue histiocytosis. Laboratory Investigation, 33, 371-378.

Hovig, T., and Gjone, E. (1973). Ultrastructural aspects of familial lecithin/cholesterol acyltransferase deficiency. Nutrition and Metabolism, 15, 89-96.

Long, R. G., Lake, B. D., Pettit, J. E., Scheuer, P. J., and Sherlock, S. (1977). Adult Niemann-Pick disease: its relationship to the syndrome of the sea-blue histiocyte. American Journal of Medicine, 62, 627-635.

Lowry, O. H., Rosebrough, N. J., Farr, A. L., and Randall, R. J. (1951). Protein measurement with the Folin phenol reagent. Journal of Biological Chemistry, 193, 265-275.

Lynn, R., and Terry, R. D. (1964). Lipid histochemistry and electron microscopy in adult Niemann-Pick disease. American Journal of Medicine, 37, 987-994.

Moeschlin, S. (1947). Die Milzpunktion: Technik, diagnostiche und hämatologische Ergebnisse, pp. 37-38. B. Schwabe, Basle.
Parker, A. C., Bain, A. D., Brydon, W. G., Harkness, R. A., Smith, A. F., Smith, I. I., and Boyd, D. H. A. (1976). Sea blue histiocytosis associated with hyperlipidaemia. Journal of Clinical Pathology, 29, 634-638.

Sawitsky, A., Rosner, F., and Chodsky, S. (1972). The sea-blue histiocyte syndrome. A review: genetic and biochemical studies. Seminars in Hematology, 9, 285-297.

Schneider, E. L., Pentchev, P. G., Hibbert, S. R., Sawitsky, A., and Brady, R. O. (1978). A new form of Niemann-Pick disease characterised by temperaturelabile sphingomyelinase. Journal of Medical Genetics, 15, 370-374.

Silverstein, M. N., and Ellefson, R. D. (1972). The syndrome of the sea-blue histiocyte. Seminars in Hematology, 9, 299-307.

Silverstein, M. N., Ellefson, R. D., and Ahern, E. J. (1970). The syndrome of the sea-blue histocyte. New England Journal of Medicine, 282, 1-4.

Snyder, R. A., and Brady, R. O. (1969). The use of white cells as a source of diagnostic material for lipid storage diseases. Clinica Chimica Acta, 25, 331-338.

Steinberg, M. H., and Dreiling, B. J. (1973). Chronic granulocytic leukemia. Prolonged survival, muscle infiltration and sea-blue histiocytes. American Journal of Medicine, 55, 93-98.

Wenger, D. A., Barth, G., and Githens, J. H. (1977). Nine cases of sphingomyelin lipidosis, a new variant in Spanish-American children. American Journal of Diseases of Children, 131, 955-961.

Requests for reprints to: Dr A. C. Parker, The Royal Infirmary of Edinburgh, Edinburgh EH3 9YW, UK. 